\title{
Changes in Salivary Parameters of Oral Immunity after Biologic Therapy for Inflammatory Bowel Disease
}

\author{
Kacper Nijakowski ${ }^{1, *(\mathbb{D}}$, Rafał Rutkowski ${ }^{2}$, Piotr Eder ${ }^{3} \mathbb{D}$, Katarzyna Korybalska ${ }^{2} \mathbb{D}$, Janusz Witowski ${ }^{2} \mathbb{D}$ \\ and Anna Surdacka ${ }^{1}$ (D) \\ 1 Department of Conservative Dentistry and Endodontics, Poznan University of Medical Sciences, \\ 60-812 Poznan, Poland; annasurd@ump.edu.pl \\ 2 Department of Pathophysiology, Poznan University of Medical Sciences, 60-806 Poznan, Poland; \\ rrutkowski@ump.edu.pl (R.R.); koryb@ump.edu.pl (K.K.); jwitow@ump.edu.pl (J.W.) \\ 3 Department of Gastroenterology, Dietetics and Internal Diseases, Poznan University of Medical Sciences, \\ 60-355 Poznan, Poland; piotreder@ump.edu.pl \\ * Correspondence: kacpernijakowski@ump.edu.pl
}

Citation: Nijakowski, K.; Rutkowski,

R.; Eder, P.; Korybalska, K.; Witowski,

J.; Surdacka, A. Changes in Salivary Parameters of Oral Immunity after Biologic Therapy for Inflammatory Bowel Disease. Life 2021, 11, 1409. https://doi.org/10.3390/life11121409

Academic Editor: Yi Dai

Received: 19 November 2021

Accepted: 15 December 2021

Published: 16 December 2021

Publisher's Note: MDPI stays neutral with regard to jurisdictional claims in published maps and institutional affiliations.

Copyright: (c) 2021 by the authors. Licensee MDPI, Basel, Switzerland. This article is an open access article distributed under the terms and conditions of the Creative Commons Attribution (CC BY) license (https:// creativecommons.org/licenses/by/ $4.0 /)$.

\begin{abstract}
We previously observed that inflammatory bowel disease (IBD) may compromise oral host defense, as assessed by decreased salivary levels of immunoglobulin A (IgA) and myeloperoxidase (MPO). Biologic therapy with inhibitors of cytokines or adhesion molecules is increasingly used for patients with IBD. Little is known, however, about how this treatment modality affects the release and properties of saliva. Here, we aimed to determine how biologic therapy in patients who had not responded to previous standard treatment with conventional drugs affected the salivary concentration of $\operatorname{IgA}$ and MPO. To this end, unstimulated whole mixed saliva was collected before treatment or after 10-12 weeks of therapy from 27 patients with Crohn's disease (CD) and 24 patients with ulcerative colitis (UC). After the induction phase of therapy with biologics, salivary levels of $\operatorname{IgA}$ and MPO increased significantly in UC, but not in CD patients. These increases were approximately 8-fold and 6-fold, for IgA and MPO, respectively. Moreover, these effects occurred in UC patients who responded successfully to therapy, but not in those who failed to improve. Furthermore, the relative increases in salivary IgA and MPO correlated with the relative decrease in UC severity, as assessed by the Mayo scale. These data indicate that the successful therapy with biologics in UC patients results also in improved oral host defense. However, it remains to be determined why such an effect does not occur during therapy for CD.
\end{abstract}

Keywords: inflammatory bowel disease; biologic therapy; saliva; biomarkers; myeloperoxidase; immunoglobulin A; oral immunity; oral health; Crohn's disease; ulcerative colitis

\section{Introduction}

Despite many studies and research efforts over the years, the actual etiopathogenesis of inflammatory bowel disease (IBD) is still unknown. The two major forms of IBD are Crohn's disease (CD) and ulcerative colitis (UC). According to the Guidelines of the Working Group of the National Consultant in Gastroenterology and the Polish Society of Gastroenterology for the management of patients with Crohn's disease and ulcerative colitis, as well as modified recommendations of the European Crohn's and Colitis Organisation (ECCO), the primary goal of treatment for IBD should be to achieve and then maintain clinical remission without the use of steroids. The first-line treatment for moderate IBD is based primarily on 5-aminosalicylic acid (5-ASA) derivatives (mesalazine and sulfasalazine) with or without corticosteroids. In cases of 5-ASA treatment failure and steroid resistance, steroid dependence or intolerance, thiopurines can be used [1-6].

For patients refractory to conventional therapy, the use of tumor necrosis factor-alpha $(\mathrm{TNF} \alpha)$ inhibitors (infliximab, adalimumab, and certolizumab pegol) is recommended. Other biologic therapies may include vedolizumab (a monoclonal antibody against $\alpha 4 \beta 7$ 
integrin) and ustekinumab (a monoclonal antibody against the $\mathrm{p} 40$ subunit of cytokines IL-12 and IL-23) [7]. All biologics are administered by the intravenous route, except for adalimumab administered by the subcutaneous route and subsequent subcutaneous doses of ustekinumab (after the first intravenous dose). At the time of the study, the treatment of patients with Crohn's disease with infliximab and adalimumab and with ulcerative colitis with infliximab and vedolizumab was reimbursed in Poland.

In view of the current pandemic situation, a special Position Paper of the Polish Society of Gastroenterology and the National Consultant in Gastroenterology on the management of patients with inflammatory bowel disease in the era of the COVID-19 pandemic was published last April [8]. It is recommended to continue the current treatment in patients in clinical remission. The predominance of subcutaneously administered biologic drugs has been suggested due to the shorter length of stay in the facility and the possibility of administration at home, so this should be considered when implementing a new therapy. An additional factor indicating adalimumab as the anti-TNF- $\alpha$ drug of first choice is the lower risk of antibody formation compared with infliximab. However, it is not recommended to switch from the current intravenous formulation to another subcutaneous formulation because of the increased risk of disease exacerbation. In contrast, vedolizumab is preferred for the treatment of older patients because it is less likely to increase the risk of concomitant infections. In addition, high doses of steroids should be avoided with the consideration of reducing the current dose. However, there is no clear evidence of an increased risk of SARS-CoV-2 infection when patients routinely take the drugs.

The effect of IBD on salivation and the properties of saliva is only partially under-stood. The salivary concentrations of a number of different molecules have been shown to change during IBD [9]. These include primarily mediators of inflammation and oxidative stress. Interestingly, we recently observed that in patients with long-lasting IBD unresponsive to conventional treatment, the concentration of some effectors of immunity was significantly lower than in healthy controls [10]. This effect was rather surprising, given that other studies [11-14] reported mainly on increased levels of several salivary components in IBD. We hypothesized that such a direction of changes could be related to immunosuppression caused by previous treatment attempts, rather than reflect the degree of inflammation induced by the disease.

Of the many components of saliva, immunoglobulin A (IgA) and myeloperoxidase (MPO) exemplify the mediators of local immunity and host defense. IgA has a defensive role by the opsonization and agglutination of bacteria, and preventing their adhesion to the epithelium of the gastrointestinal tract mucosa, including the oral cavity $[15,16]$. Altered IgA levels may predispose bacterial invasion into the mucosa, responsible for the development of erosions and ulcers [17]. Myeloperoxidase plays a role in microbial killing by neutrophils, but may also contribute to inflammation-associated tissue damage $[18,19]$. It is suggested that MPO concentrations can detect the healing of intestinal mucosa [20]. We therefore chose $\operatorname{IgA}$ and $\mathrm{MPO}$ as the parameters of oral immunity to monitor the biologic treatment in IBD.

Our study aimed to determine how biologic drugs used in induction therapy would affect the salivary biochemical parameters and how these would be related to the clinical status in IBD patients.

\section{Materials and Methods}

\subsection{Study Participants}

The study group included adult patients of both sexes, with inflammatory bowel diseases, qualified for biological treatment in the Department of Gastroenterology, Dietetics and Internal Medicine, Poznan University of Medical Sciences, between January 2019 and March 2020. All participants must have given their informed consent. Further patient recruitment was prevented by the outbreak of the COVID-19 pandemic. Of 51 patients with IBD analyzed, 27 patients had CD and 24 patients had UC. The diagnosis was based on 
clinical symptoms and endoscopic examination according to standard criteria [3,5]. Patients with concomitant autoimmune diseases (including diabetes [21]) were not included.

Patients with active, moderate to severe disease, not responding to previous conventional full-dose therapy or showing intolerance to such therapy (e.g., allergic reactions) were qualified for biological treatment. At the time of inclusion in the biologic treatment program, each patient was treated with fixed maximum doses of tolerated drugs. Patients $(n=20)$ who had previously been treated with biologics were included in the analysis if the time elapsed from previous therapy was $>18$ months $[4,5]$.

The patients were examined before and after the induction phase of therapy, i.e., after 10-14 weeks. The Crohn's Disease Activity Index (CDAI) scale [22] and the modified Mayo scale [23] were used to estimate the clinical activity of Crohn's disease and ulcerative colitis, respectively. Clinical remission in individual scales (below 150 points for $C D$ and below 2 points for UC) or a decrease in disease activity by a minimum of 100 points in CD patients or 3 points in UC patients was assumed to be the condition for determining a positive response to treatment $[24,25]$.

At both time points of the study, routine laboratory tests were performed. Fasting venous blood samples were collected in the morning. On the same day, the following laboratory parameters were determined: C-reactive protein, white blood cells, neutrophils, red blood cells, hemoglobin, hematocrit, mean corpuscular volume and platelets.

\subsection{Saliva Collection and Analysis}

Oral health was examined in all individuals using routine methods by the same investigator (K.N.). Oral hygiene (approximal plaque index, API [26]; plaque index, PII [27]) and periodontal tissues (gingival index, GI [28]; sulcus bleeding index, SBI [29]; probing periodontal depth, PPD) were assessed. Patients with periodontal disease or other overt inflammatory lesions in the oral cavity, and patients taking medications known to affect salivation [30] were not included.

Unstimulated whole mixed saliva was collected before and after the induction phase of therapy, as previously described [31]. Briefly, saliva was collected in the morning at least $2 \mathrm{~h}$ after a meal by passive drooling over $20 \mathrm{~min}$. The saliva collected was immediately analyzed for $\mathrm{pH}$ and volume, then centrifuged to remove any debris, aliquoted and placed at $-80^{\circ} \mathrm{C}$ until assayed.

Salivary concentrations of myeloperoxidase and IgA were measured with enzymelinked immunosorbent assays (respectively, DY3174, Bio-Techne, R\&D Systems, Minneapolis, MN, USA; and DEXK276, Demeditec Diagnostics, Kiel, Germany), as per manufacturer instructions. Total protein salivary concentration was measured with the Bradford method using Bio-Rad Protein Assay Dye Reagent (Bio-Rad, Munich, Germany) [32].

\subsection{The Statistical Analysis}

Since the data did not follow the normal distribution (as determined by the ShapiroWilk test), medians and quartile ranges were used for descriptive statistics, and the nonparametric the Mann-Whitney test or the Wilcoxon test were used for comparisons. For qualitative variables a two-sided Fisher exact test was performed.

Changes in parameters of disease activity and selected salivary biomarkers were calculated by subtracting the initial value from the final value (after the induction phase). The association between them was evaluated with the Spearman rank correlation.

The significance level for all analyses was set at 0.05 . The statistical analysis was performed using Statistica 13.3 (Statsoft, Cracow, Poland).

\section{Results}

\subsection{Patients Characteristics}

Table 1 shows the basic characteristics of the study group, including the clinical response to the induction therapy with the implemented biologic drug. The largest number of patients, regardless of the IBD form, were qualified for treatment with infliximab (IFX). 
While using this drug, satisfactory clinical response was observed in $3 / 4$ of CD patients and in $2 / 3$ of UC patients.

Table 1. Basic parameters describing the study group by disease form-Crohn's disease (CD) and ulcerative colitis (UC).

\begin{tabular}{|c|c|c|c|}
\hline Parameter & $\begin{array}{c}\mathrm{CD} \\
n=27\end{array}$ & $\begin{array}{c}\mathrm{UC} \\
n=24\end{array}$ & $p$-Value \# \\
\hline Gender, female, $n(\%)$ & $10(37.0)$ & $7(29.2)$ & 0.767 \\
\hline Age, years, M [Q1-Q3] & $\begin{array}{c}34.0 \\
{[28.0-48.0]}\end{array}$ & $\begin{array}{c}32.0 \\
{[24.0-40.5]}\end{array}$ & 0.171 \\
\hline Smokers, $n(\%)$ & $7(25.9)$ & $1(4.2)$ & 0.053 \\
\hline $\begin{array}{l}\text { Previous combined immunosupression } \\
\quad \text { (steroids + thiopurines), } n(\%)\end{array}$ & 7 (25.9) & $11(45.8)$ & 0.156 \\
\hline Disease duration, years, M [Q1-Q3] & $8.5[6.0-12.0]$ & $5.0[3.0-10.0]$ & 0.125 \\
\hline IFX, $n(\%)$ & $16(59.3)$ & $15(62.5)$ & $>0.999$ \\
\hline Clinical response for IFX, $n(\%)$ & $12(75.0)$ & $10(66.7)$ & 0.704 \\
\hline Other biologics $*, n(\%)$ & $11(40.7)$ & $9(37.5)$ & $>0.999$ \\
\hline Clinical response for other biologics ${ }^{*}, n(\%)$ & $11(100.0)$ & $7(77.8)$ & 0.190 \\
\hline
\end{tabular}

Legend: IFX, infliximab; *adalimumab (ADA) for CD and vedolizumab (VDZ) for UC; ${ }^{\#}$ the Mann-Whitney test for quantitative variables and the two-sided Fisher exact test for qualitative variables.

Table 2 presents the parameters of oral health in IBD patients. The study group represented good oral hygiene status and no significant differences were observed between the established subgroups. All patients manifested healthy periodontal status, with only occasional mild localized gingivitis. As expected, the periodontal status indices correlated strongly with the oral hygiene indices (not shown).

Table 2. Oral parameters describing the study group by disease form-Crohn's disease (CD) and ulcerative colitis (UC): M [Q1-Q3].

\begin{tabular}{cccc}
\hline Parameter & CD & UC & $p$-Value ${ }^{\#}$ \\
\hline Approximal plaque index $(\%)$ & $23.7[11.5-37.5]$ & $36.8[22.3-47.4]$ & 0.145 \\
Plaque index & $0.3[0.2-0.4]$ & $0.4[0.2-0.6]$ & 0.189 \\
Sulcus bleeding index $(\%)$ & $0.0[0.0-0.0]$ & $0.0[0.0-4.1]$ & 0.242 \\
Gingival index & $0.3[0.3-0.3]$ & $0.3[0.2-0.5]$ & 0.054 \\
Probing periodontal depth $(\mathrm{mm})$ & $1.3[1.2-1.6]$ & $1.4[1.2-1.5]$ & 0.624 \\
\hline
\end{tabular}

Legend: " the Mann-Whitney test.

\subsection{Comparison of IBD Activity before and after the Induction Phase of Biologic Therapy}

As expected, the introduction of biologic therapy resulted in a significant clinical improvement in patients with both CD and UC, as reflected by appropriate clinical indices (Table 3). After the induction phase of therapy, the clinical activity of the disease had already decreased significantly. This effect was associated with decreases (although not always formally significant) in CRP levels, total leukocyte, neutrophil, and platelet numbers, as well as increases in red blood cell count, hematocrit and hemoglobin concentration.

\subsection{Comparison of Salivary Properties in IBD Patients before and after the Induction Phase of Biologic Therapy}

The induction of biologic therapy for both Crohn's disease and ulcerative colitis led to an increase in both $\mathrm{pH}$ and the flow rate of unstimulated saliva (Table 4). It also resulted in increased salivary concentrations of IgA and MPO (Table 5). These, however, reached statistical significance only in the UC group. 
Table 3. Clinical and blood morphology parameters in patients with Crohn's disease (CD) and ulcerative colitis (UC) before and after the induction phase.

\begin{tabular}{|c|c|c|c|c|}
\hline Parameter & & $\begin{array}{c}\text { Before } \\
\text { Induction Phase } \\
\text { M [Q1-Q3] }\end{array}$ & $\begin{array}{c}\text { After Induction } \\
\text { Phase } \\
\text { M [Q1-Q3] }\end{array}$ & $p$-Value \\
\hline \multirow{2}{*}{$\begin{array}{l}\text { Disease severity (CDAI } \\
\text { for CD and Mayo scale } \\
\text { for UC) }\end{array}$} & $\mathrm{CD}$ & $\begin{array}{c}289.9 \\
{[203.0-332.4]}\end{array}$ & $\begin{array}{c}118.2 \\
{[60.0-203.5]}\end{array}$ & $<0.001$ * \\
\hline & $\mathrm{UC}$ & 9.0 [8.5-10.5] & $4.0[1.0-7.0]$ & $<0.001 *$ \\
\hline \multirow{2}{*}{$\mathrm{BMI}\left(\mathrm{kg} / \mathrm{m}^{2}\right)$} & $\mathrm{CD}$ & 22.1 [19.6-24.5] & $22.2[20.2-25.4]$ & $0.012 *$ \\
\hline & $\mathrm{UC}$ & 22.6 [19.7-25.7] & 22.7 [19.9-26.5] & 0.142 \\
\hline \multirow{2}{*}{$\mathrm{CRP}(\mathrm{mg} / \mathrm{L})$} & $\mathrm{CD}$ & $13.3[3.6-25.8]$ & $6.1[1.2-16.3]$ & 0.144 \\
\hline & $\mathrm{UC}$ & $5.1[1.6-12.3]$ & $2.8[1.1-6.9]$ & 0.391 \\
\hline \multirow{2}{*}{$\mathrm{WBC}\left(\times 10^{3} / \mu \mathrm{L}\right)$} & $\mathrm{CD}$ & 7.5 [6.0-11.7] & 7.3 [5.3-8.8] & 0.058 \\
\hline & $\mathrm{UC}$ & $9.8[7.2-10.7]$ & $6.3[5.6-7.8]$ & 0.001 * \\
\hline \multirow{2}{*}{$\mathrm{NEU}\left(\times 10^{3} / \mu \mathrm{L}\right)$} & $\mathrm{CD}$ & $5.1[3.9-7.4]$ & $4.0[3.2-6.3]$ & 0.170 \\
\hline & $\mathrm{UC}$ & 7.6 [4.5-8.9] & $3.5[2.8-4.3]$ & $0.004^{*}$ \\
\hline \multirow{2}{*}{$\mathrm{RBC}\left(\times 10^{6} / \mu \mathrm{L}\right)$} & $\mathrm{CD}$ & 4.7 [3.9-4.9] & $4.7[4.4-5.0]$ & 0.133 \\
\hline & $\mathrm{UC}$ & $4.5[3.5-5.0]$ & $4.8[4.2-5.2]$ & 0.011 * \\
\hline \multirow{2}{*}{$\mathrm{HGB}(\mathrm{g} / \mathrm{dL})$} & $\mathrm{CD}$ & $12.2[10.3-14.2]$ & 13.7 [12.4-14.8] & $0.003 *$ \\
\hline & $\mathrm{UC}$ & $13.0[9.5-13.8]$ & 13.5 [12.0-15.0] & $0.003 *$ \\
\hline \multirow{2}{*}{ HCT (\%) } & $\mathrm{CD}$ & 38.0 [33.6-42.9] & $41.2[38.1-44.2]$ & 0.009 * \\
\hline & UC & $39.4[30.0-42.4]$ & $40.1[35.9-44.3]$ & $0.016^{*}$ \\
\hline \multirow{2}{*}{$\operatorname{MCV}(\mathrm{fl})$} & $\mathrm{CD}$ & 87.4 [76.4-89.9] & 89.1 [85.5-91.0] & 0.062 \\
\hline & $\mathrm{UC}$ & $85.5[84.1-89.1]$ & 86.0 [84.0-88.8] & 0.830 \\
\hline \multirow{2}{*}{$\operatorname{PLT}\left(\times 10^{3} / \mu \mathrm{L}\right)$} & $\mathrm{CD}$ & $\begin{array}{c}340.0 \\
{[297.0-436.0]}\end{array}$ & $\begin{array}{c}300.0 \\
{[246.0-358.0]}\end{array}$ & $0.006^{*}$ \\
\hline & $\mathrm{UC}$ & 378 [304.0-460.0] & $\begin{array}{c}335.0 \\
{[263.0-371.5]}\end{array}$ & 0.209 \\
\hline
\end{tabular}

${ }^{*} p$-value $<0.05$ for the Wilcoxon test. Legend: CDAI, Crohn's Disease Activity Index; BMI, body mass index CRP, C-reactive protein; WBC, white blood cells; NEU, neutrophils; RBC, red blood cells; HGB, hemoglobin; HCT, hematocrit; MCV, mean corpuscular volume; PLT, platelets.

Table 4. Basic features of salivation in patients with Crohn's disease (CD) and ulcerative colitis (UC) before and after the induction phase.

\begin{tabular}{ccccc}
\hline \multirow{2}{*}{ Parameter } & IBD Form & $\begin{array}{c}\text { Before } \\
\text { Induction Phase } \\
\mathbf{M}[\mathbf{Q} 1-Q 3]\end{array}$ & $\begin{array}{c}\text { After Induction } \\
\text { Phase } \\
\text { M [Q1-Q3] }\end{array}$ & $p$-Value \\
\hline \multirow{2}{*}{$\mathrm{pH}$} & $\mathrm{CD}$ & $6.8[6.5-7.0]$ & $7.0[6.7-7.1]$ & 0.307 \\
\cline { 2 - 5 } & $\mathrm{UC}$ & $6.9[6.5-7.0]$ & $6.8[6.7-7.2]$ & $0.028^{*}$ \\
\hline $\begin{array}{c}\text { Flow rate } \\
(\mathrm{mL} / \mathrm{min})\end{array}$ & $\mathrm{CD}$ & $0.4[0.3-0.5]$ & $0.5[0.3-0.7]$ & 0.091 \\
\hline & $\mathrm{UC}$ & $0.3[0.3-0.4]$ & $0.3[0.3-0.5]$ & 0.236 \\
\hline $\begin{array}{c}\text { Total protein } \\
(\mu \mathrm{g} / \mathrm{mL})\end{array}$ & $\mathrm{CD}$ & $\begin{array}{c}254.0 \\
{[131.6-559.0]}\end{array}$ & $\begin{array}{c}358.4 \\
{[132.5-507.5]}\end{array}$ & 0.981 \\
\cline { 2 - 5 } & $\mathrm{UC}$ & $\begin{array}{c}294.0 \\
{[181.6-406.4]}\end{array}$ & 210.7 & 0.627 \\
\hline
\end{tabular}


Table 5. Comparison of concentrations of selected salivary markers in patients with Crohn's disease (CD) and ulcerative colitis (UC) before and after induction phase.

\begin{tabular}{ccccc}
\hline Parameter & IBD Form & $\begin{array}{c}\text { Before } \\
\text { Induction Phase } \\
\mathbf{M}[\mathbf{Q} 1-Q 3]\end{array}$ & $\begin{array}{c}\text { After Induction } \\
\text { Phase } \\
\text { M [Q1-Q3] }\end{array}$ & $p$-Value \\
\hline $\begin{array}{c}\mathrm{IgA} \\
(\mu \mathrm{g} / \mathrm{mL})\end{array}$ & $\mathrm{CD}$ & $52.1[0.4-175.2]$ & $112.3[8.3-151.4]$ & 0.381 \\
\hline \multirow{2}{*}{$\begin{array}{c}\text { Myeloperoxidase } \\
(\mathrm{ng} / \mathrm{mL})\end{array}$} & $\mathrm{UC}$ & $10.9[0.1-77.5]$ & $80.1[1.9-344.2]$ & $0.021{ }^{*}$ \\
\cline { 2 - 5 }${ }^{*} p$-value $<0.05$ for the Wilcoxon test. & $\mathrm{CD}$ & $57.2[4.9-110.6]$ & $78.1[7.2-195.2]$ & 0.773 \\
\hline
\end{tabular}

3.4. Comparison of Salivary Properties before and after the Induction Phase of Biologic Therapy in IBD Patients with or without Successful Response to Treatment

To see whether the changes observed were related to the response to therapy, the patients were stratified according to the treatment outcome (Tables 6 and 7). These comparisons showed that the increases in $\mathrm{pH}$, salivary flow rate and $\operatorname{Ig} \mathrm{A}$ and MPO concentrations seen in UC patients were confined to patients with a positive response to therapy. In contrast, there were no difference between CD patients with a successful and unsuccessful response to therapy. Accordingly, only in patients with $\mathrm{UC}$, the biologic therapy resulted in changes in salivary IgA and MPO levels that correlated inversely with the level of disease activity (Table 8 ). These patients showed also a significant positive correlation between changes in salivary MPO concentration and serum hemoglobin $(\mathrm{R}=0.423, p$-value $=0.040)$. There were, however, no other significant correlations with changes in salivary IgA and MPO (not shown).

Table 6. Basic features of salivation before and after the induction phase of biologic therapy in patients with Crohn's disease (CD) and ulcerative colitis (UC) with or without clinical response to treatment.

\begin{tabular}{|c|c|c|c|c|c|}
\hline Parameter & IBD Form & $\begin{array}{l}\text { Clinical } \\
\text { Response }\end{array}$ & $\begin{array}{c}\text { Before } \\
\text { Induction Phase } \\
\text { M [Q1-Q3] }\end{array}$ & $\begin{array}{c}\text { After Induction } \\
\text { Phase } \\
\text { M [Q1-Q3] }\end{array}$ & $p$-Value \\
\hline \multirow{4}{*}{$\mathrm{pH}$} & \multirow{2}{*}{ CD } & + & $6.9[6.6-7.0]$ & $6.9[6.8-7.1]$ & 0.446 \\
\hline & & - & 6.6 [6.5-6.9] & 7.0 [6.7-7.0] & 0.636 \\
\hline & \multirow{2}{*}{ UC } & + & $6.8[6.6-6.9]$ & $6.9[6.7-7.3]$ & $0.003 *$ \\
\hline & & - & $6.9[6.4-7.2]$ & 6.8 [6.6-6.9] & 0.463 \\
\hline \multirow{4}{*}{$\begin{array}{l}\text { Flow rate } \\
(\mathrm{mL} / \mathrm{min})\end{array}$} & \multirow{2}{*}{ CD } & + & $0.4[0.4-0.5]$ & $0.5[0.3-0.7]$ & 0.246 \\
\hline & & - & $0.4[0.3-0.5]$ & $0.3[0.3-0.7]$ & 0.314 \\
\hline & \multirow{2}{*}{ UC } & + & $0.3[0.3-0.4]$ & $0.4[0.3-0.5]$ & $0.026^{*}$ \\
\hline & & - & $0.3[0.3-0.8]$ & $0.3[0.2-0.3]$ & 0.249 \\
\hline \multirow{4}{*}{$\begin{array}{l}\text { Total protein } \\
\qquad(\mu \mathrm{g} / \mathrm{mL})\end{array}$} & \multirow{2}{*}{ CD } & + & $\begin{array}{c}337.7 \\
{[208.2-563.0]}\end{array}$ & $\begin{array}{c}364.2 \\
{[236.0-501.0]}\end{array}$ & 0.711 \\
\hline & & - & 181.5 [34.7-199.9] & 296.7 [91.0-611.5] & 0.594 \\
\hline & \multirow{2}{*}{ UC } & + & $\begin{array}{c}220.8 \\
{[140.0-336.0]}\end{array}$ & $187.0[36.0-377.0]$ & 0.523 \\
\hline & & - & $\begin{array}{c}817.0 \\
{[298.0-1050.0]}\end{array}$ & 351.0 [81.9-922.0] & 0.063 \\
\hline
\end{tabular}


Table 7. Comparison of concentrations of selected salivary markers before and after the induction phase of biologic therapy in patients with Crohn's disease (CD) and ulcerative colitis (UC) with or without clinical response to treatment.

\begin{tabular}{|c|c|c|c|c|c|}
\hline Parameter & IBD Form & $\begin{array}{l}\text { Clinical } \\
\text { Response }\end{array}$ & $\begin{array}{c}\text { Before } \\
\text { Induction Phase } \\
\text { M [Q1-Q3] }\end{array}$ & $\begin{array}{c}\text { After Induction } \\
\text { Phase } \\
\text { M [Q1-Q3] }\end{array}$ & $p$-Value \\
\hline \multirow{4}{*}{$\begin{array}{c}\text { Immunoglobulin } \\
\text { A } \\
(\mu \mathrm{g} / \mathrm{mL})\end{array}$} & \multirow{2}{*}{$\mathrm{CD}$} & + & $59.3[0.4-170.7]$ & 110.9 [8.3-149.5] & 0.831 \\
\hline & & - & $45.1[6.2-175.2]$ & $124.3[46.7-151.4]$ & 0.314 \\
\hline & \multirow{2}{*}{ UC } & + & $6.2[0.2-46.4]$ & $147.0[33.4-367.8]$ & $0.009 *$ \\
\hline & & - & 59.8 [0.1-90.7] & $3.0[0.2-315.7]$ & 0.917 \\
\hline \multirow{4}{*}{$\begin{array}{l}\text { Myeloperoxidase } \\
\qquad(\mathrm{ng} / \mathrm{mL})\end{array}$} & \multirow{2}{*}{$\mathrm{CD}$} & + & $69.0[8.7-103.1]$ & 74.2 [12.5-175.6] & 0.948 \\
\hline & & - & 57.2 [1.8-115.3] & $123.2[3.9-305.5]$ & 0.678 \\
\hline & \multirow{2}{*}{$\mathrm{UC}$} & + & $4.0[3.1-16.5]$ & 175.0 [11.8-199.7] & 0.004 * \\
\hline & & - & $23.9[7.6-177.3]$ & 8.1 [1.8-89.6] & 0.499 \\
\hline
\end{tabular}

* $p$-value $<0.05$ for the Wilcoxon test.

Table 8. Spearman correlation coefficients $(\mathrm{R})$ for changes in parameters of disease activity and assessed salivary biomarkers in patients with Crohn's disease (CD) and ulcerative colitis (UC).

\begin{tabular}{|c|c|c|c|c|c|c|c|c|}
\hline \multirow{3}{*}{ Parameter } & \multicolumn{4}{|c|}{$\Delta \operatorname{IgA}(\mu \mathrm{g} / \mathrm{mL})$} & \multicolumn{4}{|c|}{$\Delta \mathrm{MPO}(\mathrm{ng} / \mathrm{mL})$} \\
\hline & \multicolumn{2}{|c|}{ CD } & \multicolumn{2}{|c|}{ UC } & \multicolumn{2}{|c|}{ CD } & \multicolumn{2}{|c|}{ UC } \\
\hline & $\mathbf{R}$ & $p$-Value & $\mathbf{R}$ & $p$-Value & $\mathbf{R}$ & $p$-Value & $\mathbf{R}$ & $p$-Value \\
\hline $\begin{array}{l}\Delta \text { Disease severity } \\
\text { (CDAI for CD and } \\
\text { Mayo scale for UC) }\end{array}$ & -0.164 & 0.415 & $-0.421^{*}$ & 0.041 & -0.015 & 0.942 & $-0.546^{*}$ & 0.006 \\
\hline
\end{tabular}

* significant correlation for $p$-value $<0.05$ according to the Spearman rank correlation. Legend: CDAI, Crohn's Disease Activity Index; IgA, immunoglobulin A; MPO, myeloperoxidase; $\Delta$, subtracting the initial value from the final value (after the induction phase).

\section{Discussion}

In our recent study [10], we observed that salivary levels of myeloperoxidase and to a lesser extent of IgA were decreased in UC patients compared to both healthy controls and patients with CD. We hypothesized that such a difference could be related to previous dual immunosuppression regimens that were more commonly used by UC patients. Here, we show that the induction phase of subsequent therapy with biologics resulted in a significant increase in salivary $\operatorname{IgA}$ and MPO in UC but not in CD patients. Importantly, this effect occurred only in UC patients who responded satisfactorily to therapy.

According to this concept, the therapy with biologics restored the oral host defense that was compromised by prior immune suppression. In this respect, it was observed that the use of glucocorticoids decreased neutrophil production, which was associated with decreased concentrations of myeloperoxidase in body fluids, including the sputum [33].

In contrast to our observations, several other studies reported increased IgA in patients with active IBD [11,34-36]. However, this effect could be attributed to the presence of abnormalities in oral mucosa, which were absent in our group of patients.

Interestingly, we observed an increase in the $\mathrm{pH}$ of saliva in UC patients who responded to therapy. It needs to be determined whether such an effect can be at least partly related to the increase in MPO observed in these patients. This is because MPO in neutrophils is known to create and maintain an alkaline milieu important for effective phagocytosis [37].

It is difficult to relate observations of the present study to earlier reports, as previous studies did not seem to take into account the history of immunosuppression typically used in IBD patients. Furthermore, in our study, we found no significant correlation between salivary MPO and IgA with disease activity assessed before the initiation of therapy. This 
may be because the indexes of disease severity were generally high at this point. In addition, the disease activity scales have strong subjective components, which may limit their relationship with biochemical parameters.

Fecal calprotectin is commonly used for monitoring the response to treatment and healing of the intestinal mucosa $[38,39]$. In the only previous study examining the effect of biologic therapy for IBD on salivary parameters, Majster et al. [40] compared calprotectin levels in saliva before and after therapy. They found no significant differences in calprotectin levels in both unstimulated and stimulated saliva following 10-12 weeks of therapy. They did, however, observe a profound decrease in serum calprotectin as a result of therapy. This discrepancy may indicate that the levels of calprotectin in saliva correspond only weakly to the serum calprotectin concentration.

In this respect, Majster et al. [41] compared the levels of inflammatory cytokines in the saliva and blood from IBD patients, and related them to disease activity. In contrast to significant changes in the serum levels of many cytokines, there were only slight changes in the saliva that did not associate with disease activity.

Our research model with therapeutic intervention (induction phase of biologic treatment) had a relatively homogeneous study group in terms of oral health status. Among the few studies performed to date on the release and properties of saliva in IBD, our investigation is unique in that it assessed the direct impact of biologic therapy in patients with both UC and CD. In this respect, the observed differences between these forms of IBD are puzzling. They can be partly related to the pathobiology of the disease itself but also to the immunomodulatory effect of therapy, as the greatest differences occurred in UC patients who successfully responded to treatment. The limitations of the study included the fact that further patient recruitment to increase the power of the study was hampered by the COVID-19 pandemic. For the same reason, the direct supervision of saliva sampling was not always possible. Therefore, it is desirable for further studies to confirm the relationships observed. Furthermore, it would be useful to correlate the levels of markers determined in saliva with their levels in blood serum.

\section{Conclusions}

The relationship between clinical response to biologic therapy and salivary parameters of oral immunity in patients with inflammatory bowel disease cannot be clearly established. As a result of induction therapy, only patients with ulcerative colitis showed a significant increase in salivary IgA and myeloperoxidase to levels comparable to the controls. In patients with Crohn's disease, as well as in patients with no clinical response, there were no significant changes in the measured levels of salivary markers. Our investigation demonstrated the potential use of non-invasive diagnostics with saliva to monitor the course of biological treatment in IBD patients, although further studies are required.

Author Contributions: Conceptualization, K.N., A.S., P.E. and J.W.; methodology, A.S., P.E., K.K. and J.W.; formal analysis, K.N.; investigation and resources, K.N., P.E. and R.R.; writing-original draft preparation, K.N.; writing_review and editing, K.N., A.S. and J.W.; visualization, K.N. and J.W.; supervision, A.S., P.E. and J.W. All authors have read and agreed to the published version of the manuscript.

Funding: This research received no external funding.

Institutional Review Board Statement: The study was conducted according to the guidelines of the Declaration of Helsinki, and approved by the Bioethics Committee of Poznan University of Medical Sciences (1266/18-6 December 2018).

Informed Consent Statement: Informed consent was obtained from all subjects involved in the study.

Data Availability Statement: Data are available on request from the corresponding author.

Conflicts of Interest: The authors declare no conflict of interest. 


\section{References}

1. Łodyga, M.; Eder, P.; Bartnik, W.; Gonciarz, M.; Kłopocka, M.; Linke, K.; Małecka-Panas, E.; Radwan, P.; Reguła, J.; Rydzewska, G. Guidelines for the Management of Crohn's Disease. Recommendations of the Working Group of the Polish National Consultant in Gastroenterology and the Polish Society of Gastroenterology. Gastroenterol. Rev. 2013, 7, 317-338. [CrossRef]

2. Eder, P.; Łodyga, M.; Łykowska-Szuber, L.; Bartnik, W.; Durlik, M.; Gonciarz, M.; Kłopocka, M.; Linke, K.; Małecka-Panas, E.; Radwan, P.; et al. Guidelines for the Management of Ulcerative Colitis. Recommendations of the Working Group of the Polish National Consultant in Gastroenterology and the Polish Society of Gastroenterology. Gastroenterol. Rev. 2013, 8, 1-20. [CrossRef]

3. Magro, F.; Gionchetti, P.; Eliakim, R.; Ardizzone, S.; Armuzzi, A.; Barreiro-de Acosta, M.; Burisch, J.; Gecse, K.B.; Hart, A.L.; Hindryckx, P.; et al. Third European Evidence-Based Consensus on Diagnosis and Management of Ulcerative Colitis. Part 1: Definitions, Diagnosis, Extra-Intestinal Manifestations, Pregnancy, Cancer Surveillance, Surgery, and Ileo-Anal Pouch Disorders. J. Crohns Colitis 2017, 11, 649-670. [CrossRef]

4. Harbord, M.; Eliakim, R.; Bettenworth, D.; Karmiris, K.; Katsanos, K.; Kopylov, U.; Kucharzik, T.; Molnár, T.; Raine, T.; Sebastian, S.; et al. Third European Evidence-Based Consensus on Diagnosis and Management of Ulcerative Colitis. Part 2: Current Management. J. Crohns Colitis 2017, 11, 769-784. [CrossRef] [PubMed]

5. Gomollón, F.; Dignass, A.; Annese, V.; Tilg, H.; Van Assche, G.; Lindsay, J.O.; Peyrin-Biroulet, L.; Cullen, G.J.; Daperno, M.; Kucharzik, T.; et al. 3rd European Evidence-Based Consensus on the Diagnosis and Management of Crohn's Disease 2016: Part 1: Diagnosis and Medical Management. J. Crohns Colitis 2017, 11, 3-25. [CrossRef] [PubMed]

6. Gionchetti, P.; Dignass, A.; Danese, S.; Magro Dias, F.J.; Rogler, G.; Lakatos, P.L.; Adamina, M.; Ardizzone, S.; Buskens, C.J.; Sebastian, S.; et al. 3rd European Evidence-Based Consensus on the Diagnosis and Management of Crohn's Disease 2016: Part 2: Surgical Management and Special Situations. J. Crohns Colitis 2017, 11, 135-149. [CrossRef] [PubMed]

7. Łodyga, M.; Eder, P.; Bartnik, W.; Gonciarz, M.; Kłopocka, M.; Linke, K.; Małecka-Panas, E.; Radwan, P.; Rydzewska, G. New Pharmaceuticals in Inflammatory Bowel Disease. Gastroenterol. Rev. 2015, 10, 57-60. [CrossRef]

8. Łodyga, M.; Eder, P.; Dobrowolska, A.; Reguła, J.; Rydzewska, G. Position Paper of the Polish Society of Gastroenterology and the National Consultant in Gastroenterology on the Management of Patients with Inflammatory Bowel Disease in the Era of the COVID-19 Pandemic. Available online: http:/ / www.ptg-e.org.pl/Stanowisko-Polskiego-Towarzystwa-Gastroenterologiii-Konsultanta-Krajowego-w-Dziedzinie-Gastroenterologii-dotyczace-postepowania-z-pacjentem-Z-nieswoista-chorobazapalna-jelit-w-dobie-pandemii-COVID,299.html (accessed on 30 April 2021).

9. Nijakowski, K.; Surdacka, A. Salivary Biomarkers for Diagnosis of Inflammatory Bowel Diseases: A Systematic Review. Int. J. Mol. Sci. 2020, 21, 7477. [CrossRef]

10. Nijakowski, K.; Rutkowski, R.; Eder, P.; Simon, M.; Korybalska, K.; Witowski, J.; Surdacka, A. Potential Salivary Markers for Differential Diagnosis of Crohn's Disease and Ulcerative Colitis. Life 2021, 11, 943. [CrossRef]

11. Said, H.S.; Suda, W.; Nakagome, S.; Chinen, H.; Oshima, K.; Kim, S.; Kimura, R.; Iraha, A.; Ishida, H.; Fujita, J.; et al. Dysbiosis of Salivary Microbiota in Inflammatory Bowel Disease and Its Association with Oral Immunological Biomarkers. DNA Res. 2014, 21, 15-25. [CrossRef]

12. Szczeklik, K.; Owczarek, D.; Pytko-Polończyk, J.; Kęsek, B.; Mach, T.H. Proinflammatory Cytokines in the Saliva of Patients with Active and Non-Active Crohn's Disease. Pol. Arch. Med. Wewn. 2012, 122, 200-208. [CrossRef]

13. Nielsen, A.A.; Nielsen, J.N.; Schmedes, A.; Brandslund, I.; Hey, H. Saliva Interleukin-6 in Patients with Inflammatory Bowel Disease. Scand. J. Gastroenterol. 2005, 40, 1444-1448. [CrossRef]

14. Szczeklik, K.; Krzyściak, W.; Cibor, D.; Domagała-Rodacka, R.; Pytko-Polończyk, J.; Mach, T.; Owczarek, D. Markers of Lipid Peroxidation and Antioxidant Status in the Serum and Saliva of Patients with Active Crohn Disease. Pol. Arch. Intern. Med. 2018, 128, 362-370. [CrossRef] [PubMed]

15. Holmgren, J.; Czerkinsky, C. Mucosal Immunity and Vaccines. Nat. Med. 2005, 11, S45-S53. [CrossRef] [PubMed]

16. Marcotte, H.; Lavoie, M.C. Oral Microbial Ecology and the Role of Salivary Immunoglobulin A. Microbiol. Mol. Biol. Rev. MMBR 1998, 62, 71-109. [CrossRef]

17. Finamore, A.; Peluso, I.; Cauli, O. Salivary Stress/Immunological Markers in Crohn's Disease and Ulcerative Colitis. Int. J. Mol. Sci. 2020, 21, 8562. [CrossRef]

18. Aratani, Y. Myeloperoxidase: Its Role for Host Defense, Inflammation, and Neutrophil Function. Arch. Biochem. Biophys. 2018, 640, 47-52. [CrossRef]

19. van der Veen, B.S.; de Winther, M.P.J.; Heeringa, P. Myeloperoxidase: Molecular Mechanisms of Action and Their Relevance to Human Health and Disease. Antioxid. Redox Signal. 2009, 11, 2899-2937. [CrossRef] [PubMed]

20. Masoodi, I.; Tijjani, B.M.; Wani, H.; Hassan, N.S.; Khan, A.B.; Hussain, S. Biomarkers in the Management of Ulcerative Colitis: A Brief Review. GMS Ger. Med. Sci. 2011, 9, 3. [CrossRef]

21. Surdacka, A.; Ciężka, E.; Pioruńska-Stolzmann, M.; Wender-Ożegowska, E.; Korybalska, K.; Kawka, E.; Kaczmarek, E.; Witowski, J. Relation of Salivary Antioxidant Status and Cytokine Levels to Clinical Parameters of Oral Health in Pregnant Women with Diabetes. Arch. Oral Biol. 2011, 56, 428-436. [CrossRef]

22. Best, W.R.; Becktel, J.M.; Singleton, J.W.; Kern, F. Development of a Crohn's Disease Activity Index. National Cooperative Crohn's Disease Study. Gastroenterology 1976, 70, 439-444. [CrossRef]

23. Schroeder, K.W.; Tremaine, W.J.; Ilstrup, D.M. Coated Oral 5-Aminosalicylic Acid Therapy for Mildly to Moderately Active Ulcerative Colitis. A Randomized Study. N. Engl. J. Med. 1987, 317, 1625-1629. [CrossRef] 
24. D’Haens, G.; Sandborn, W.J.; Feagan, B.G.; Geboes, K.; Hanauer, S.B.; Irvine, E.J.; Lémann, M.; Marteau, P.; Rutgeerts, P.; Schölmerich, J.; et al. A Review of Activity Indices and Efficacy End Points for Clinical Trials of Medical Therapy in Adults with Ulcerative Colitis. Gastroenterology 2007, 132, 763-786. [CrossRef]

25. Peyrin-Biroulet, L.; Panés, J.; Sandborn, W.J.; Vermeire, S.; Danese, S.; Feagan, B.G.; Colombel, J.-F.; Hanauer, S.B.; Rycroft, B. Defining Disease Severity in Inflammatory Bowel Diseases: Current and Future Directions. Clin. Gastroenterol. Hepatol. 2016, 14, 348-354.e17. [CrossRef]

26. Lange, D.E.; Plagmann, H.C.; Eenboom, A.; Promesberger, A. Clinical methods for the objective evaluation of oral hygiene. Dtsch. Zahnarztl. Z. 1977, 32, 44-47.

27. Silness, J.; Löe, H. Periodontal Disease in Pregnancy. II. Correlation between Oral Hygiene and Periodontal Condition. Acta Odontol. Scand. 1964, 22, 121-135. [CrossRef] [PubMed]

28. Löe, H.; Silness, J. Periodontal Disease in Pregnancy. I. Prevalence and Severity. Acta Odontol. Scand. 1963, 21, 533-551. [CrossRef] [PubMed]

29. Mühlemann, H.R.; Son, S. Gingival Sulcus Bleeding-A Leading Symptom in Initial Gingivitis. Helv. Odontol. Acta 1971, 15, 107-113. [PubMed]

30. Pedersen, A.M.L.; Sørensen, C.E.; Proctor, G.B.; Carpenter, G.H.; Ekström, J. Salivary Secretion in Health and Disease. J. Oral Rehabil. 2018, 45, 730-746. [CrossRef]

31. Navazesh, M. Methods for Collecting Saliva. Ann. N. Y. Acad. Sci. 1993, 694, 72-77. [CrossRef] [PubMed]

32. Bradford, M.M. A Rapid and Sensitive Method for the Quantitation of Microgram Quantities of Protein Utilizing the Principle of Protein-Dye Binding. Anal. Biochem. 1976, 72, 248-254. [CrossRef]

33. Barczyk, A.; Sozañska, E.; Trzaska, M.; Pierzchala, W. Decreased Levels of Myeloperoxidase in Induced Sputum of Patients with COPD after Treatment with Oral Glucocorticoids. Chest 2004, 126, 389-393. [CrossRef] [PubMed]

34. Warner, R.H.; Stevens, F.M.; McCarthy, C.F. Salivary SIgA and SIgA 1 in Coeliac Disease, Inflammatory Bowel Disease and Controls. Ir. J. Med. Sci. 1999, 168, 33-35. [CrossRef]

35. Savage, N.W.; Barnard, K.; Shirlaw, P.J.; Rahman, D.; Mistry, M.; Escudier, M.P.; Sanderson, J.D.; Challacombe, S.J. Serum and Salivary IgA Antibody Responses to Saccharomyces Cerevisiae, Candida Albicans and Streptococcus Mutans in Orofacial Granulomatosis and Crohn's Disease. Clin. Exp. Immunol. 2004, 135, 483-489. [CrossRef]

36. Janšáková, K.; Escudier, M.; Tóthová, L'.; Proctor, G. Salivary Changes in Oxidative Stress Related to Inflammation in Oral and Gastrointestinal Diseases. Oral Dis. 2021, 27, 280-289. [CrossRef]

37. Arnhold, J. The Dual Role of Myeloperoxidase in Immune Response. Int. J. Mol. Sci. 2020, 21, 8057. [CrossRef] [PubMed]

38. Cui, G.; Fan, Q.; Li, Z.; Goll, R.; Florholmen, J. Evaluation of Anti-TNF Therapeutic Response in Patients with Inflammatory Bowel Disease: Current and Novel Biomarkers. EBioMedicine 2021, 66, 103329. [CrossRef]

39. State, M.; Negreanu, L.; Voiosu, T.; Voiosu, A.; Balanescu, P.; Mateescu, R.B. Surrogate Markers of Mucosal Healing in Inflammatory Bowel Disease: A Systematic Review. World J. Gastroenterol. 2021, 27, 1828-1840. [CrossRef]

40. Majster, M.; Almer, S.; Boström, E.A. Salivary Calprotectin Is Elevated in Patients with Active Inflammatory Bowel Disease. Arch. Oral Biol. 2019, 107, 104528. [CrossRef]

41. Majster, M.; Lira-Junior, R.; Höög, C.M.; Almer, S.; Boström, E.A. Salivary and Serum Inflammatory Profiles Reflect Different Aspects of Inflammatory Bowel Disease Activity. Inflamm. Bowel Dis. 2020, 26, 1588-1596. [CrossRef] 